\title{
PEMANFAATAN GOOGLE DRIVE DALAM PENILAIAN MANDIRI PELAKSANAAN REFORMASI BIROKRASI (PMPRB) DI PEMERINTAH PROVINSI KEPULAUAN RIAU
}

\author{
Askarmin Harun ${ }^{1}$, Shariyani ${ }^{2}$ \\ ${ }^{1}$ Program Studi Ilmu Pemerintahan, Fakultas Ilmu Sosial dan Ilmu Politik, Universitas Riau Kepulauan, Batam, \\ Indonesia \\ askarmin@rocketmail.com
}

\begin{abstract}
Abstrak
Reformasi 1998 menunjukkan adanya gerakan sosial masyarakat yang mendorong adanya perubahan terhadap krisis multidimensi dalam bidang ekonomi, politik, hukum dan Birokrasi. Perubahan tersebut dilandasi oleh keinginan untuk mewujudkan pemerintahan yang demokratis, bersih dan mempercepat terwujudnya kesejahteraan rakyat. Reformasi pada bidang birokrasi menjadi bagian yang cukup penting dalam upaya mewujudkan pemerintahan yang bersih. Reformasi Birokrasi dapat mewujudkan penyelenggaraan tata kelola Pemerintahan yang baik (good governance), profesional dan berintegritas tinggi baik pada pemerintahan pusat maupun daerah. Penilaian pelaksanaan reformasi birokrasi pada pemerintah daerah adalah bentuk kongkrit penerapan nilai-nilai reformasi birokrasi yang akuntabel dan terukur. Seiring perkembangan zaman yang didorong dengan kemajuan teknologi, pemanfaatan media dapat digunakan sebagai penunjang pelaksanaan reformasi birokrasi. Pemanfaatan media juga dapat membuat pelaksanaan reformasi birokrasi terlaksana secara transparan dan akuntabel.

Kata Kunci : Reformasi Birokrasi, good governance, Media.
\end{abstract}

\begin{abstract}
Abstact
The 1998 reforms showed the existence of a social movement of the people that led to changes in the multidimensional crisis in the economic, political, law and bureaucratic. This change is based on the desire to create a democratic, clean government and accelerate the realization of people's welfare. Reforms in the bureaucratic sector have become an important part of efforts to create a clean government. Bureaucratic Reform can realize the implementation of good governance, good governance and high integrity both at central and regional governments. Evaluation of the implementation of bureaucratic reform in local government is a concrete form of applying the values of bureaucratic reform that is accountable and measurable. Along with the times that are driven by technological advances, the use of media can be used to support the implementation of bureaucratic reform. The use of media can also make the implementation of bureaucratic reform carried out transparently and accountably.

Key Word: Bureaucratic Reform, good governance, Media.
\end{abstract}

\section{PENDAHULUAN}

Pada tahun 1997, Indonesia mengalami kirisis moneter yang mengakibatkan perekenomian Indonesia menjadi lemah. Berdasarkan penelitian sebelumnya, krisis moneter 1977 ditandai dengan krisis nilai tukar rupiah yang kemudian meluas dengan cepat menjadi krisis keuangan yang sangat dalam (Romida, 2013: 321). Pada tahun 1998 krisis yang dialami oleh Indonesia telah berkembang menjadi krisis multidimensi. Kondisi tersebut mengakibatkan adanya tuntutan yang kuat dari segenap lapisan masyarakat. Tuntutan masyarakat terhadap pemerintah ialah untuk segera diadakan reformasi. muncul gerakan- 
gerakan sosial baru untuk memperbaiki keadaan dengan langsung turun ke jalan (Gigih, 2016: 12).

Tuntutan gerakan-gerakan sosial yang menuntut adanya perubahan yang kemudian dikenal secara luas dengan istilah reformasi 1998, membuat terjadi berbagai perubahan penting yang menjadi awal dimulainya era reformasi tidak hanya di bidang ekonomi, dan politik, tapi juga pada bidang hukum, dan birokrasi. Reformasi pada awal ini dikenal sebagai reformasi gelombang pertama. Perubahan tersebut dilandasi oleh keinginan masyarakat untuk mewujudkan pemerintahan yang demokratis, bersih dan mempercepat terwujudnya kesejahteraan rakyat sebagaimana tertuang dalam Pembukaan UUD 1945 yang sebelumnya tidak dirasakan pada masa orde baru (Wardana dan Meiwanda, 2017: 332).

Dalam perkembangan pelaksanaan reformasi gelombang pertama, reformasi di bidang birokrasi tidak secara signifikan dilakukan dibanding reformasi di bidang politik, ekonomi, dan hukum. Oleh karena itu, pada tahun 2004, pemerintah telah menegaskan kembali akan pentingnya penerapan prinsip-prinsip clean government dan good governance yang secara universal yang diyakini menjadi prinsip yang diperlukan untuk memberikan pelayanan prima kepada masyarakat. Berkaitan dengan hal tersebut, program utama yang dilakukan pemerintah adalah membangun aparatur negara melalui penerapan reformasi birokrasi. Dengan demikian, reformasi birokrasi gelombang pertama pada dasarnya secara bertahap mulai dilaksanakan pada tahun 2004. Hal ini ditandai dengan dimasukkannya pembahasan mengenai reformasi birokrasi didalam Peraturan Presiden Nomor 7 Tahun 2005 Tentang Rencana Pembangunan Jangka Menengah Nasional Tahun 2004 - 2009.

Pada Tahun 2008 sebagai bentuk keseriusan dalam upaya melaksanakan reformasi birokrasi, Pemerintah mengeluarkan Peraturan Menteri Pendayagunaan Aparatur Negara Nomor:Per/15/M.Pan/7/2008 Tentang Pedoman Umum Reformasi Birokrasi. Didalam Peraturan tersebut terdapat pembahasan mengenai arah kebijakan, implementasi program serta evaluasi pelaksanaan Reformasi Birokrasi. Adanya peraturan ini menunjukkan arah baru pelaksanaan reformasi birokrasi. Berikut kerangka keseluruhan awal pelaksanaan pelaksanaan Reformasi Birokrasi di Indonesia: 

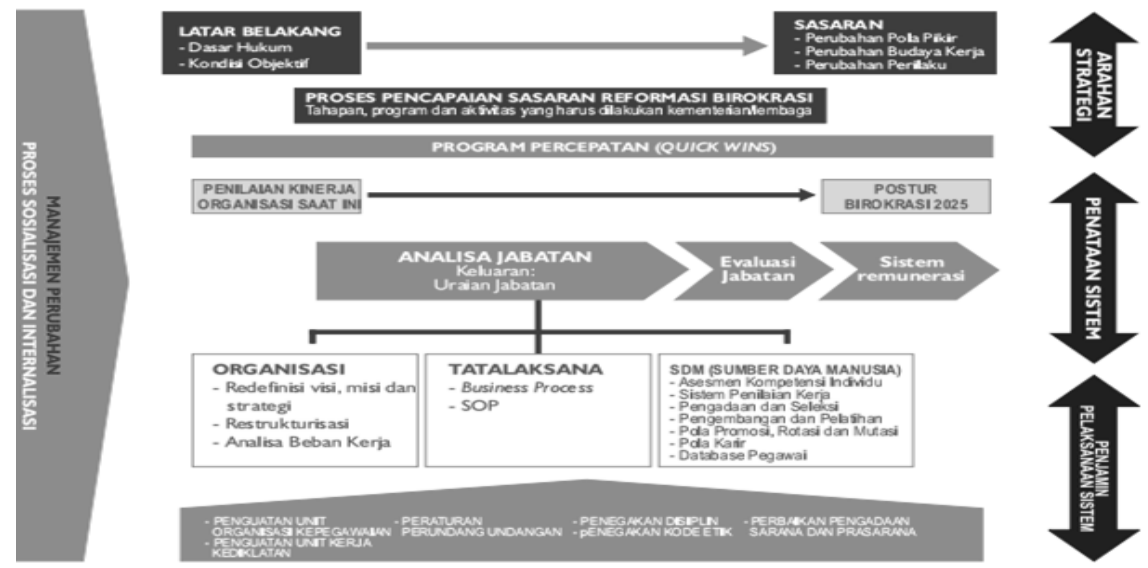

Gambar 1 Kerangka Reformasi Birokrasi

Sumber : Permenpan Nomor Per/ 15 /M.Pan/7/2008

Pada tahun 2009 merupakan tahun terakhir pelaksanaan reformasi gelombang pertama, artinya pelaksanaan reformasi sudah masuk pada gelombang kedua. Reformasi gelombang kedua bertujuan untuk membebaskan Indonesia dari dampak dan ekor krisis yang terjadi 10 tahun yang lalu. Pada tahun 2025 Indonesia diharapkan berada pada fase yang benar-benar bergerak menuju negara maju (Darto, 2011: 255). Pada periode ini Pelaksanaan reformasi birokrasi terus ditingkatkan. Kementerian Pemberdayaan Aparatur Negara berubah nama menjadi Kementerian Pemberdayaan Aparatur Negara dan Reformasi Birokrasi. Hal ini menunjukkan adanya keseriuan pemerintah untuk meningkatkan reformasi birokrasi pada reformasi gelombang kedua.

Kementerian, Lembaga dan Pemerintah Daerah juga dituntut ikut andil dalam melaksanakan Reformasi Birokrasi. Berdasarkan Peraturan Menteri Pendayagunaan Aparatur Negara Nomor PER/04/M.PAN/4/2009 Tentang Pedoman Pengajuan dokumen Usulan Reformasi Birokrasi di Lingkungan Kementerian, Lembaga dan Pemerintah Daerah. Sebelum secara resmi melaksanakan agenda Reformasi Birokrasi Kementerian, Lembaga dan Pemerintah Daerah diberi kesempatan untuk memberikan usulan rencana program Reformasi Birokrasi.

Pada Tahun 2010 secara resmi Komite Pengarah dan Tim Reformasi Birokrasi Nasional dibentuk. Melalui Keputusan Presiden Republik Indonesia Nomor 14 Tahun 2010 TentangPembentukan Komite Pengarah Reformasi Birokrasi Nasionaldan Tim Reformasi Birokrasi Nasional, tugas pokok Komite Pengarah ialah menetapkan kebijakan,strategi, dan 
standar-standar bagi pelaksanaan program reformasi birokrasi dan kinerja operasi birokrasi secara nasional yang kemudian secara teknis di lakukan oleh Tim Reformasi Birokrasi Nasional dengan menyusun rancangan Grand Design dan Road Map Reformasi Birokrasi dalam rentang tahun 2010-2025 yang mencakup delapan area perubahan.

Pada Tahun 2011, seluruh Kementerian, Lembaga dan Pemerintah Daerah ditargetkan telah memiliki komitmen dalam melaksanakan proses reformasi birokrasi. Kemuidan pada tahun 2014 secara bertahap dan berkelanjutan, Kementerian, Lembaga dan Pemerintah Daerah telah memiliki kekuatan untuk memulai proses tersebut, sehingga pada tahun 2025 , birokrasi pemerintahan yang profesional dan berintegritas tinggi dapat diwujudkan.

Pemerintah Provinsi Kepulauan Riau, dalam hal merespon arahan Pemerintah Pusat melalui Gubernur Kepualuan Riau yang merupakan perpanjangan tangan Pemerintah Pusat di Daerah mengeluarkan Peraturan Gubernur Nomor 11 Tahun 2012 tentang Reformasi Birokrasi di Lingkungan Pemerintah Provinsi Kepulauan Riau. Maksud dan tujuan diberlakukannya aturan tersebut adalah sebagai upaya untuk mewujudkan penyelenggaraan tata kelola Pemerintahan yang baik pada seluruh Perangkat Daerah di provinsi kepulauan riau, sesuai dengan asas umum penyelenggaraan negara yang baik (good governance).

Pelaksanaan Reformasi Birokrasi secara teknis di Pemerintah Provinsi Kepulauan Riau dilakukan dengan melaksanakan Penilaian Mandiri Pelaksanaan Reformasi Birokrasi (PMPRB) sejak Tahun 2016. PMPRB adalah bentuk evaluasi yang dilakukan oleh Pemerintah Pusat melalui Kementerian Pendayagunaan Aparatur Negara dan Reformasi Birokrasi guna mengukur tercapainya pelaksanaan Reformasi Birokrasi disetiap Kementerian, Lembaga dan Pemerintah Daerah. Proses ini dilakukan secara online berdasarkan Peraturan Menteri Pendayagunaan Aparatur Negara dan Reformasi Birokrasi Nomor 31 Tahun 2012 tentang tentang Petunjuk TeknisPenilaian Mandiri Pelaksanaan Reformasi Birokrasi Secara Online.

Pada Tahun 2019 pelaksanaan PMPRB secara teknis di Pemerintah Provinsi Kepulauan Riau belum terlaksana dengan baik. Hal ini disebabkan banyak Perangkat Daerah yang menjadi sasaran penilaian pelaksanaan reformasi birokrasi terkendala dengan menyajikan data dukung yang diperlukan, kegiatan ini adalah kegiatan rutin setiap tahun dan pelaksanaan PMPRB di Provinsi Kepulauan Riau sudah berjalan sejak Tahun 2016 seharusnya Perangkat Daerah yang menjadi sasaran penilaian sudah memiliki data dukung yang sesuai penilaian. Beberapa hal yang menjadi kendala, yakni pegawai yang mengurusi 
reformasi birokrasi di Perangkat Daerah terkait pindah tugas ke Perangkat Daerah lain, serta belum adanya arsip data yang baik terkait data dukung reformasi birokrasi.

Banyak hal yang dapat menjadi alternatif dalam mengatasi sulitnya Perangkat Daerah menyediakan data dukung untuk mempercepat pelaksanaan Penilaian Mandiri Pelaksanaan Reformasi Birokrasi (PMPRB), salah satunya ialah dengan digitalisasi data atau menyimpan data secara online menggunakan Google Drive, selain mempercepat pelaksanaan PMPRB hal ini juga dapat memberikan keterbukaan informasi terkait perkembangan Reformasi Birokrasi di Pemerintah Provinsi Kepulauan Riau. Preseiden melalui Inpres Nomor 3 Tahun 2003 tentang Kebijakan dan Strategi Nasional Pengembangan e-government, menuntut terbentuknya Pemerintahan yang bersih, transparan, dan mampu menjawab tuntutan perubahan secara efektif. Hal ini juga mendorong Pemerintah Provinsi Kepulauan Riau mengeluarkan Peraturan Gubernur Kepulauan Riau Nomor 76 Tahun 2017 tentang Tata Kerja Pengelola Layanan Informasi dan Dokumentasi di Lingkungan Pemerintah Provinsi Kepulauan Riau guna mewujudkan penyelenggaraan pemerintahan yang baik, transparan, efektif dan efisien, akuntabel serta dapat dipertanggungjawabkan.

\section{METODELOGI}

Adapun metode yang digunakan penulis adalah deskriptif kualitatif yaitu dengan memusatkan perhatian pada masalah-masalah yang ada pada saat penelitian dilakukan atau masalahmasalah yang bersifat aktual dan menggambarkan fakta-fakta tentang masalah yang diselidiki sebagaimana adanya dan diiringi dengan interpretasi rasional (Hadari, 1993). Dengan demikian diharapkan isu partisipasi dapat dikemukakan sebagaimana adanya secara lengkap dan diikuti dengan pemberian analisa dan interpretasi.

\section{PEMBAHASAN}

\section{Penilaian Mandiri Pelaksanaan Reformasi Birokrasi (PMPRB)}

Penilaian Mandiri Pelaksanaan Reformasi Birokrasi (PMPRB) merupakan instrumen penilaian kemajuan pelaksanaan reformasi birokrasi yang dilakukan secara mandiri (self assessement) oleh Kementerian, Lembaga dan Pemerintah Daerah. PMPRB memfokuskan penilaian terhadap langkah-langkah reformasi birokrasi yang dilakukan oleh setiap instansi pemerintah dikaitkan dengan hasil yang diharapkan dan juga dikaitkan dengan Indikator Kinerja Utama instansi pemerintah dalam rangka pencapaian 
sasaran dan indikator keberhasilan pelaksanaan reformasi birokrasi secara nasional sebagaimana tertuang dalam Grand Design Reformasi Birokrasi 2010-2025. Dapat juga disimpulkan bahwa PMPRB adalah penilaian sementara yang berasal dari penilaian mandiri Kementerian, Lembaga dan Pemerintah Daerah sebelum Kementerian PAN dan RB mengeluarkan nilai resmi yang selanjutnya menjadi catatan pelaksanaan Reformasi birokrasi.

Pada Tahun 2012 Kementerian Pendayagunaan Aparatur Negara dan Reformasi telah menerbitkan Permen PAN dan RB Nomor 1 Tahun 2012 tentang Pedoman Penilaian Pelaksanaan Reformasi Birokrasi dan Permen PAN dan RB Nomor 31 Tahun 2012 tentang Petunjuk Teknis Penilaian Mandiri Pelaksanaan Reformasi Birokrasi Secara Online. Kedua aturan ini menjadi instrumen untuk mengukur keberhasilan pelaksanaan Reformasi Birokrasi di Kementerian, Lembaga dan Pemerintah Daerah.

Dalam PMPRB terdapat dua kompenen peniliaian yakni kompenen pengungkit dan kompenen hasil. Komponen pengungkit adalah seluruh aspek internal organisasi instansi pemerintah yang melakukan berbagai upaya manajemen untuk mewujudkan output dan outcome bagi masyarakat/pengguna layanan, SDM Aparaturnya, dan bagi komunitas lokal, nasional dan internasional, serta mewujudkan kinerja yang menjadi tujuannya sehingga kompenen hasil merupakan output dan/atau outcome yang dihasilkan Komponen Pengungkit. Berikut diagram kriteria penilaian dalam PMPRB awal:

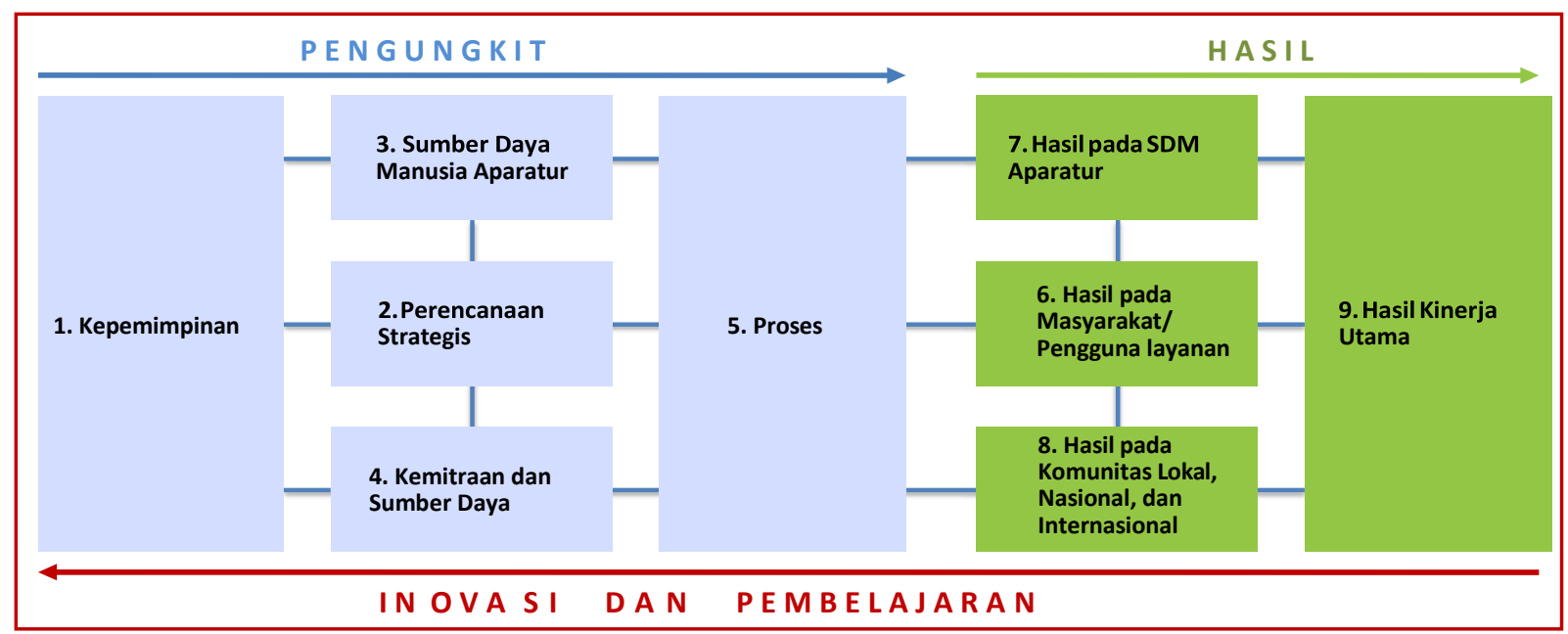

Gambar 2 Komponen Penilai Reformasi Birokrasi

Sumber: Permenpan dan RB Nomor 1 Tahun 2012

Delapan unsur yang terdapat dalam diagram tersebut menjadi komponen dalam penilaian PMPRB. Kementerian, Lembaga dan Pemerintah Daerah diminta untuk menyiapkan bukti-bukti yang relevan seperti dokumen, surat menyurat, notulen rapat, produk 
hukum, foto, dll atas ketercapaian terhadap kompenen penilaian yang sudah dituangkan dalam Permen PAN dan RB Nomor 1 Tahun 2012 tentang Pedoman Penilaian Mandiri Pelaksanaan Reformasi Birokrasi (PMPRB). Secara teknis pada jadwal yang sudah ditetapkan, Kementerian, Lembaga dan Pemerintah Daerah diminta login ke dalam sistem PMPRB online melalui http://pmprb.menpan.go.id dengan menggunakan akun yang telah diberikan untuk mengisi kuesioner secara online. Responden hanya diberikan rentang waktu tertentu sesuai masa berlakunya akun responden untuk mengisi kuesioner, untuk menghindari pengisian yang subjektif.

Seiring berkembangnya waktu Pada Tahun 2014 Pemerintah menerbitkan Peraturan Menteri Pendayagunaan Aparatur Negara dan Reformasi Birokrasi Nomor 14 tahun 2014 tentang Pedoman Evaluasi Reformasi Birokrasi Instansi Pemerintah. Peraturan ini lebih praktis mengukur keberhasilan pelaksanaan Reformasi Birokrasi di Kementerian, Lembaga dan Pemerintah Daerah. Peraturan ini juga mempermudah instansi pusat dan daerah dalam mengisi secara mandiri serta mengidentifikasi perubahan-perubahan yang sudah, sedang, dan akan dilakukan, untuk kemudian hasilnya disampaikan kepada Kementerian PAN dan RB secara online untuk dievaluasi. Berikut komponen penilaian yang terdapat dalam aturan tersebut beserta delapan area perubahan yang menjadi progress penilaian Reformasi Birokrasi:

Tabel 1 Bobot Penilaian Reformasi Birokrasi

\begin{tabular}{|c|c|c|c|}
\hline No & Komponen & Bobot & Sub-Komponen \\
\hline 1 & $\begin{array}{l}\text { Komponen } \\
\text { Pengungkit }\end{array}$ & $60 \%$ & $\begin{array}{l}\text { a. Manajemen perubahan (5\%) } \\
\text { b.Penataanperaturanperundang- } \\
\text { undangan (5\%) } \\
\text { c. Penataandan penguatan } \\
\text { organisasi }(6 \%) \\
\text { d.Penataan tatalaksana (5\%) } \\
\text { e. Penataan sistem manajemen } \\
\text { SDM (15\%) } \\
\text { f. Penguatan Akuntabilitas }(6 \%) \\
\text { g. Penguatan pengawasan }(12 \%) \\
\text { h.Peningkatankualitaspelayanan } \\
\text { publik }(6 \%)\end{array}$ \\
\hline 2 & $\begin{array}{l}\text { Komponen } \\
\text { Hasil }\end{array}$ & $40 \%$ & $\begin{array}{l}\text { a. Kapasitasdan akuntabilitas } \\
\text { organisasi }(20 \%) \\
\text { b.Pemerintah yang bersih dan } \\
\text { bebas KKN (10\%) } \\
\text { c. Kualitas pelayanan publik }(10 \%)\end{array}$ \\
\hline & Total & $100 \%$ & \\
\hline
\end{tabular}

Sumber : Permenpan dan RB nomor 14 Tahun 2014 
Dari tabel tersebut dapat terlihat bahwa indikator penilaian jauh lebih terukur ditambah dengan adanya bobot nilai yang telah ditetapkan. Berikut kategori penilaian Reformasi Birokrasi yang telah ditetapkan oleh Kementerian PAN dan RB:

Tabel 2 Ketegori Penilaian Reformasi Birokrasi

\begin{tabular}{|c|c|c|c|}
\hline \multirow{2}{*}{ No. } & \multirow{2}{*}{ Kategori } & Nilai & \multirow{2}{*}{ Interprestasi } \\
\hline & & Angka & \\
\hline 1 & $\mathrm{AA}$ & $>90-100$ & Istimewa \\
\hline 2 & A & $>80-90$ & Memuaskan \\
\hline 3 & BB & $>70-80$ & Sangat Baik \\
\hline 4 & $\mathrm{~B}$ & $>60-70$ & Baik, perlu sedikit perbaikan \\
\hline 5 & $\mathrm{CC}$ & $>50-60$ & $\begin{array}{l}\text { Cukup (memadai), perlu banyak } \\
\text { perbaikan yang tidak mendasar }\end{array}$ \\
\hline 6 & $\mathrm{C}$ & $>30-50$ & $\begin{array}{l}\text { Kurang, perlu banyak sekali } \\
\text { perbaikan \& perubahan yang } \\
\text { sangat mendasar }\end{array}$ \\
\hline 7 & $\mathrm{D}$ & $>0-30$ & $\begin{array}{l}\text { Sangat Kurang, perlu banyak } \\
\text { sekali perbaikan \& perubahan } \\
\text { yang sangat mendasar }\end{array}$ \\
\hline
\end{tabular}

Sumber : Permenpan dan RB nomor 14 Tahun 2014

Pelaksanaan PMPRB secara rinci dapat di laksanakan melalui tahapan-tahapan sebagai berikut: Rapat bersama Perangkat Daerah penanggung jawab; Perangkat Daerah mengirimkan data dukung ke Inspektorat dan Biro Organisasi; Inspektorat mengisi data RB ke LKE di website; Biro Organisasi meneruskan nilai PMPRB hasil pengisian LKE oleh inspektorat ke Sekretaris Daerah (jika Sekretaris Daerah setujuh, Biro Organisasi dan Korpri langsung meneruskan ke Kementrerian PAN dan RB, jika tidak di kembalikan kembali Inspektorat untuk ditindaklanjuti); Biro Organisasi mengirimkan seluruh data dukung dari Perangkat Daerah ke Kementerian PAN dan RB.

\section{Reformasi Birokrasi di Pemerintah Provinsi Kepulauan Riau}

Pemerintah Provinsi Kepulauan Riau secara konsisten telah melaksanakan program reformasi birokrasi sejak Tahun 2012, hal ini ditandai dengan disusunnya Peraturan Gubernur Kepulauan Riau Nomor 11 Tahun 2012 tentang Reformasi Birokrasi di Lingkungan Pemerintah Provinsi Kepulauan Riau serta Road Map Reformasi Birokrasi Provinsi Kepulauan Riau Tahun 2012-2015 melalui Keputusan Gubernur Kepulauan Riau Nomor 713 Tahun 2013 Tentang Road Map Reformasi Birokrasi Pemerintah Provinsi Kepulauan Riau Tahun 2012-2015. Road map ini menggambarakan capaian dan rencana aksi pelaksanaan 
reformasi birokrasi di Pemerintah Provinsi Kepulauan Riau berdasarkan komponen penilai yang telah ditetapkan oleh Kementerian PAN dan RB.

Seiring berjalannya waktu untuk mengukur secara jelas keberhasilan Pemerintah Provinsi Kepulauan Riau dalam melaksanakan Reformasi Birokrasi, maka pada Tahun 20162018 Pemerintah Provinsi Kepulauan Riau ikut dalam pelaksanaan PMPRB melalui web yang telah disediakan oleh Kementerian PAN dan RB yang kemudian di evaluasi kembali. Berikut nilai Reformasi Birokrasi Pemerintah Provinsi Kepulauan Riau selama 3 tahun berturut-turut yang merupakan hasil evaluasi Kementerian PAN dan RB:

Tabel 3 Nilai Reformasi Birokrasi Pemerintah Provinsi Kepulauan Riau Tahun 2016-2018

\begin{tabular}{|c|l|c|c|c|c|}
\hline \multirow{2}{*}{ NO } & \multicolumn{1}{|c|}{ Komponen Penilaian } & \multirow{2}{*}{ Bobot } & \multicolumn{3}{c|}{ Nilai } \\
\cline { 4 - 6 } & & & $\mathbf{2 0 1 6}$ & $\mathbf{2 0 1 7}$ & $\mathbf{2 0 1 8}$ \\
\hline I & Komponen Pengungkit & & & & \\
\hline 1 & Manajemen Perubahan & 5.00 & 1.92 & 1.92 & 2.05 \\
\hline 2 & Penataan Peraturan Perundang-undangan & 5.00 & 2.71 & 2.71 & 2.71 \\
\hline 3 & Penataan dan Penguatan Organisasi & 6.00 & 2.84 & 2.84 & 3.18 \\
\hline 4 & Penataan Tatalaksana & 5.00 & 3.30 & 3.43 & 3.04 \\
\hline 5 & Penataan Sistem Manajemen SDM & 15.00 & 10.52 & 11.34 & 12.29 \\
\hline 6 & Penguatan Akuntabilitas & 6.00 & 4.12 & 4.35 & 4.46 \\
\hline 7 & Penguatan Pengawasan & 12.00 & 4.45 & 4.88 & 3.83 \\
\hline 8 & Peningkatan Kualaitas Pelayanan Publik & 6.00 & 2.51 & 2.51 & 3.92 \\
\hline & Total Komponen Pengungkit (A) & $\mathbf{6 0 . 0 0}$ & $\mathbf{3 2 . 3 7}$ & $\mathbf{3 3 . 9 8}$ & $\mathbf{3 5 . 4 8}$ \\
\hline II & Komponen Hasil & & & & \\
\hline 1 & Nilai Akuntabilitas Kinerja & 14.00 & 9.61 & 9.84 & 9.82 \\
\hline 2 & Survei Internal Integritas Organisasi & 6.00 & 4.44 & 4.38 & 3.67 \\
\hline 3 & Survei Eksternal Persepsi Korupsi & 7.00 & 5.46 & 5.58 & 5.76 \\
\hline 4 & Opini BPK & 3.00 & 3.00 & 3.00 & 3.00 \\
\hline 5 & Survei Eksternal Pelayanan Publik & 10.00 & 7.85 & 7.40 & 8.10 \\
\hline & Total Komponen Hasil (B) & $\mathbf{4 0 . 0 0}$ & $\mathbf{3 0 . 3 6}$ & $\mathbf{3 0 . 2 0}$ & $\mathbf{3 0 . 3 5}$ \\
\hline & Indeks Reformasi Birokrasi (A+B) & $\mathbf{6 2 . 7 3}$ & $\mathbf{6 4 . 1 8}$ & $\mathbf{6 5 . 8 3}$ \\
\hline
\end{tabular}

Sumber : Kemen PAN dan RB 
Dari data tersebut dapat disimpulkan bahwa pelaksanaan Reformasi Birokrasi di Pemerintah Provinsi Kepulauan Riau tiga tahun berturut-turut mengalami peningkatan dengan indeks nilai "B".

Pada Tahun 2019, Pemerintah Provinsi Kepulauan Riau kembali melaksanakan PMPRB guna mendapatkan evaluasi Pelaksanaan Reformasi Birokrasi di Pemerintah Provinsi Kepulauan Riau. Dalam Indikator penilaian Reformasi Birokrasi yang telah ditetapkan oleh Kementerian PAN dan RB, maka terdapat beberapa perangkat Daerah yang menjadi sasaran pelaksanaan Reformasi Birokrasi sesuai dengan komponen penilaian. Pada Tahun ini pula Penilaian PMPRB sesuai surat Kementerian PAN dan RB Nomor B/70/PW.00/2019 tentang Penyampaian PMPRB dan Pengajuan unit kerja ZI menuju WBK/WBBM Tahun 2019, Kementerian PAN dan RB meminta data dukung dibuat dalam bentuk soft copy serta melibatkan dua kelompok Perangkat Daerah, yakni Perangkat Daerah penanggungjawab Reformasi Birokrasi Provinsi dan Perangkat Daerah Sample. Berikut data kelompok Perangkat Daerah yang dimaksud:

Tabel 4 Perangkat Daerah Sasaran Penilaian PMPRB

\begin{tabular}{|c|c|}
\hline Perangkat Daerah Penanggungjawab & Perangkat Daerah Sample \\
\hline $\begin{array}{l}\text { 1. Inspektorat Daerah Provinsi Kepulauan } \\
\text { Riau } \\
\text { 2. Badan Perencanaan, Penelitian dan } \\
\text { Pengembangan Provinsi Kepulauan Riau } \\
\text { 3. Badan Pengelolaan Pajak dan Retribusi } \\
\text { Daerah Provinsi Kepulauan Riau } \\
\text { 4. Badan Kepegawaian dan Pengembangan } \\
\text { Sumber Daya Manusia Provinsi } \\
\text { Kepulauan Riau } \\
\text { 5. Dinas Kesehatan Provinsi Kepulauan Riau } \\
\text { 6. Dinas Komunikasi dan Informatika } \\
\text { Provinsi Kepulauan Riau } \\
\text { 7. Dinas Penanaman Modal dan Pelayanan } \\
\text { Terpadu Satu Pintu Provinsi Kepulauan } \\
\text { Riau } \\
\text { 8. Dinas Perpustakaan dan Kearsipan } \\
\text { Provinsi Kepulauan Riau } \\
\text { 9. Biro Hukum Sekretariat Daerah Provinsi } \\
\text { Kepulauan Riau } \\
\text { 10. Biro Organisasi dan KORPRI Sekretariat } \\
\text { Daerah Provinsi Kepulauan Riau }\end{array}$ & $\begin{array}{l}\text { 1. Inspektorat Daerah Provinsi Kepulauan } \\
\text { Riau } \\
\text { 2. Badan Perencanaan, Penelitian dan } \\
\text { Pengembangan Provinsi Kepulauan Riau } \\
\text { 3. Badan Kepegawaian dan Pengembangan } \\
\text { Sumber Daya Manusia Provinsi } \\
\text { Kepulauan Riau } \\
\text { 4. Dinas Kesehatan Provinsi Kepulauan } \\
\text { Riau } \\
\text { 5. Dinas Komunikasi dan Informatika } \\
\text { Provinsi Kepulauan Riau } \\
\text { 6. Dinas Penanaman Modal dan Pelayanan } \\
\text { Terpadu Satu Pintu Provinsi Kepulauan } \\
\text { Riau } \\
\text { 7. Dinas Perpustakaan dan Kearsipan } \\
\text { Provinsi Kepulauan Riau } \\
\text { 8. Dinas Pariwisata Provinsi Kepulauan } \\
\text { Riau } \\
\text { 9. Dinas Pekerjaan Umum, Penataan Ruang } \\
\text { dan Pertanahan Provinsi Kepulauan Riau } \\
\text { 10. Dinas Kelautan dan Perikanan Provinsi } \\
\text { Kepulauan Riau }\end{array}$ \\
\hline
\end{tabular}


Keseluruhan Perangkat Daerah tersebut wajib mengisi nama dokumen dan melengkapi data sesuai indikator yang telah ditetapkan melalui LKE (Lembar Kerja Evaluasi) yang ada di web pmprb.menpan.com.

Inspektorat Provinsi Kepulauan Riau bersama Biro Organisasi dan Korpri adalah Perangkat Daerah yang menjadi leading Sector pelaksanaan PMPRB di Pemerintah Provinsi Kepulauan Riau. Inspektorat bertugas sebagai tim review dan eksekutor pengisian Lembar Kerja Evaluasi (LKE) di website PMPRB. Biro Organisasi dan Korpri sebagai perpanjangan tangan Sekretaris Daerah bertugas memfasilitasi, mengkoordinasikan dan memastikan Seluruh Perangkat Daerah yang menjadi sasaran pelaksanaan Reformasi Birokrasi Pemerintah Provinsi Kepulauan Riau melaksanakan PMPRB sesuai dengan jadwal yang telah di tentukan Kementerian PAN dan RB.

Dalam pelaksanaannya, Banyak perangkat Daerah terutama Perangkat Daerah penanggungjawab Reformasi Birokrasi Provinsi Kepulauan Riau yang kesulitan menyediakan data dukung yang sesuai dengan indikator penilaian Reformasi Birokrasi. PMPRB pada Pemerintah Provinsi Kepulauan Riau telah dilaksanakan sejak Tahun 2016 seharusnya kendala tersebut tidak lagi terjadi. Hal ini menjadi menghambat pelaksanaan PMPRB. Beberapa hal yang menjadi kendala diantarnya adalah tidak adanya arsip data khusus terkait pelaksanaan Reformasi Birokrasi, terlebih saat ini Kementerian PAN dan RB meminta data dukung di kirim dengan bentuk soft copy. Untuk itu harus ada media yang mampu menjadi penyimpan data sekaligus mampu menjadi arsip data untuk selanjutnya mempermudah evaluasi di setiap tahunnya. Seiring perkembangan zaman media yang baik dijadikan sebagai Media penyimpanan data ialah media online. Media online yang sering digunakan saat ini ialah Google Drive dengan memanfaatkan menu Folder sebab memiliki penyimpanan yang cukup besar dan bisa di akses secara terbuka, kapan saja dan dimana saja.

\section{Pemanfaatan Google Drive dalam Percepatan Pelaksanaan Penilaian Mandiri} Pelaksanaan Reformasi Birokrasi (PMPRB) di Pemerintah Provinsi Kepulauan Riau

Google Drive adalah sebuah media penyimpanan online tak terbatas, bisa diakses kapanpun dan dimanapun. Google Drive dapat digunakan sebagai penyimpan data yang juga banyak diterapkan dalam beberapa hal. Fiqih Ismawan, Puput Irfansyah, dan Dwi Dani Apriyani dalam Jurnal dengan judul Pengoptimalan Cloud Storage-Google Drive Sebagai Media Pembelajaran Untuk Guru SMP dan SMA, menunjukkan bahwa Google Drive dapat 
menjadi media penyimpan online yang baik serta dapat dimanfaatkan secara lebih sebagai media pembelajaran (Ismawan, Irfansyah, dan Dani, 2018: 61).

Dalam pelaksanaan Reformasi Birokrasi, Googke Drive dapat dimanfaatkan sebagai media penyimpan data Reformasi Birokrasi Perangkat Daerah yang kemudian dapat memudahkan pelaksanaan PMPRB. Setiap Perangkat Daerah yang menjadi penanggungjawab pelaksanaan Reformasi Birokrasi Pemerintah Provinsi Kepulauan Riau membuat folder di dalam google drive kemudian mengupload seluruh data terkait Reformasi Birokrasi yang menjadi indikator penilaian sesuai Permen PAN dan RB. Berikut diagram alur pembuatan Folder dalam Google Drive untuk data Reformasi Birokrasi:

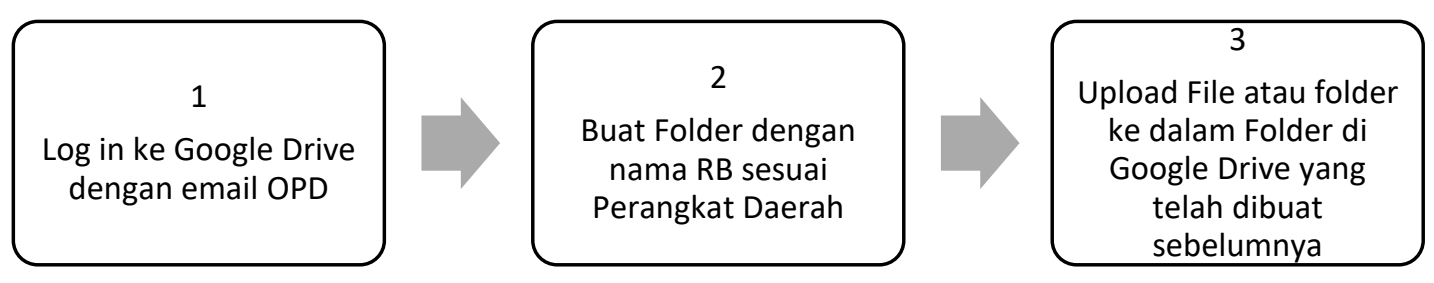

Gambar 3 Diagram alur pembuatan Google Drive untuk RB

Ket:

1. Masuk ke Google Drive.com kemudian log in menggunakan email Perangkat Daerah

2. Buat folder dengan nama RB beserta nama perangkat daerah misal "RB Diskominfo"

3. Masukkan seluruh data RB yang sesuai dengan indikator yang telah ditetapkan Kementerian PAN dan RB

kemudian Perangkat Daerah menyiapkan link folder tersebur dan mengirimkan ke Biro Organisasi, kemudian Biro Organisasi merangkum seluruh data dari Perangkat Daerah yang kemudian dikirim ke Kementerian PAN dan RB. Berikut alur selanjutnya:

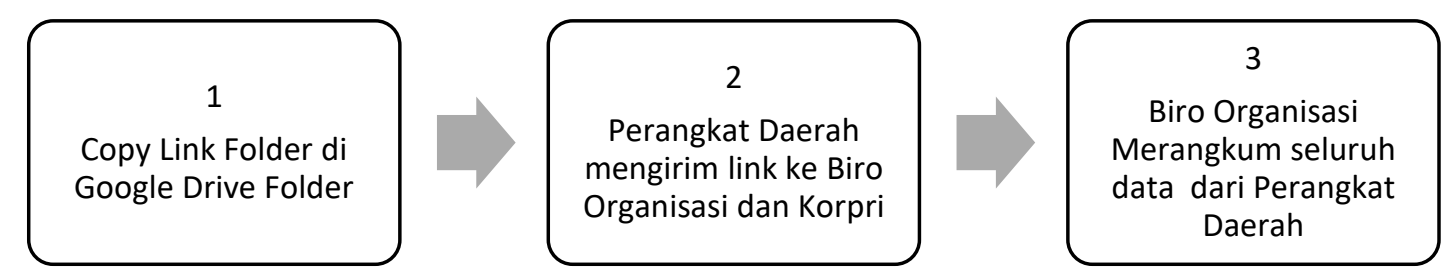

Gambar 4 Alur Pengiriman Data Reformasi Birokrasi

Ket:

1. Copy Link Folder di Google Drive misal menjadi "Bitly//:RBDISKOMINFO2019".

2. Perangkat Daerah mengirim link yang sudah ada ke Biro Organisasi. 
3. Biro Organisasi Merangkum seluruh data dari Perangkat Daerah untuk selanjutnya di teruskan ke Kementerian PAN dan RB.

Proses ini mampu membuat data Reformasi Birokrasi di Perangkat Daerah terdokumentasi dengan baik, serta dapat diakses dimanapun dan kapan pun, sehingga mempermudah dan mempercepat pelaksanaan PMPRB di Pemerintah Provinsi Kepulauan Riau. Selanjutnya jika ada perubahan data, dapat dirubah secara mudah dengan mengupload kembali ke Google Drive sesuai akun masing-masing Perangkat Daerah.

\section{KESIMPULAN}

Dalam upaya melaksanakan Reformasi Birokrasi di Pemerintah Provinsi Kepulauan Riau, perlu adanya kerjasama yang baik antara Perangkat Daerah yang menjadi sasaran penilaian Reformasi Birokrasi bersama-sama dengan leading sector Pelaksanaan Reformasi Birokrasi yang dalam hal ini adalah Inspektorat dan Biro Organisasi dan Korpri Provinsi Kepulauan Riau.

Google Drive dapat menjadi media terbaik dalam upaya mempercepat pelaksanaan Penilaian Mandiri Pelaksanaan Reformasi Birokrasi (PMPRB). Penggunaannya yang ringkas, mudah, dapat diakses dimana saja dan kapan saja, mampu membuat pelaksanaan Penilaian Reformasi Birokrasi di Pemerintah Provinsi Kepulauan Riau terlaksana dengan transparan, akuntabel, efektif dan efisien.

\section{DAFTAR PUSTAKA}

Wardana, Data dan Geovani Meiwanda. (2017). Reformasi Birokrasi Menuju Indonesia Baru, Bersih dan Bermartabat. Wedana: Jurnal Pemerintahan Politik dan Birokrasi. 3 (1).

Ismawan, Fiqih, Puput Irfansyah, dan Dwi Dani Apriyani. (2018). Pengoptimalan Cloud Storage-Google Drive Sebagai Media Pembelajaran Untuk Guru SMP dan SMA. Jurnal: Pengabdian Kepada Masyarakat. 1 (1).

Darto, Muhammad. (2011). Asa Baru Reformasi Birokrasi Gelombang Kedua. Jurnal Borneo Administrator: 7 (3).

Harahap, Siti Romida. (2013). Deteksi Dini Krisis Nilai Tukar Indonesia : Identifikasi Periode Krisis Tahun 1995-2011. Economics Developments Analysis Journal: 2 (4).

Gigih Prasisko, Yongky. (2016). Gerakan Sosial Baru Indonesia: Reformasi 1998 dan Proses Demokratis Indonesia. Jurnal Pemikiran Sosiologi: 3 (2). 